\title{
The View from the Bottom: How Small Businessmen Learned to Love Yiwu
}

DOI: $10.32870 /$ mycp.v13i37.336

\author{
Guillermo Ruiz-Stovel ${ }^{1}$ \\ 有钱能使鬼推磨 \\ If you have money \\ you can make ghosts \\ turn your grindstone \\ —Chinese proverb
}

\section{Introduction}

7 he mid-sized city of Yiwu, located in central Zhejiang province, takes it reputation very seriously. Its hard-earned title as "China's small

1 commodities city" is not to be taken lightly. ${ }^{2}$ With the reforms of the early 1980s, this sleepy market town opened its eyes after a thirty-year long Maoist interlude. Its low-end, low-cost goods were soon being sold beyond local and provincial markets. Yiwu became the domestic distribution center for "small commodities," attracting small entrepreneurs from around the country who were hoping to ride the Yiwu wave and strike it rich. It wasn't long before the word got out. For years now, Yiwu's markets have been filled with Middle Eastern, African, Indian, Russian, Thai, and Latin American importers. Trading companies (often ran by the buyers' own countrymen) consolidate containers with the goods bought from vendors operating in the city's wholesale (pifa 批发) markets.

Yiwu has provided business solutions for legions of small importers. Yet it no longer lives in the shadows as a "trade secret." Yiwu now openly advertises

1. Profesor Investigador del Departamento de Estudios del Pacífico, del Centro Universitario de Ciencias Sociales y Humanidades de la Universidad de Guadalajara. ORCID http:// orcid.org/0000-0001-6873-8704

2. A literal translation of Yiwu's domestic brand identity: Zhongguo xiao shangpin cheng 中国小 商品城. 
at the Canton Fair and on the internet. It even holds its own international trade fair in October. Both its airport and its markets have been recently revamped. Yiwu's suppliers are diversifying, offering not only low-cost generic goods, but also better quality equivalents which are more likely to attract buyers from industrialized countries.

Little has been published on the Yiwu wholesale phenomenon outside of China, and most has been within a journalistic context and as part of

glosses on the Chinese export economy in the specialized business press. It is therefore important to clarify from the outset what this piece is and what it isn't. This is not a rigorous analysis of the market forces at play in Yiwu or their social and cultural implications. At best, it is an attempt at a scholarly inspired travel literature, a first-person account by a vocationally confused historian temporarily dabbling in the China trade. My hope is that despite its methodological foibles, this piece will shed light on some of the issues and idiosyncratic features of the Yiwu case which undoubtedly warrant a more detailed treatment.

\section{Yiwu: Up Close and Personal}

It was three-thirty in the morning. Stepping onto the platform, I heard the conductor loudly announce that train N511 had reached its final destination. My back was covered in sweat. There had not been much difference between the temperature inside the train car and that out in the open. Wrapped in clammy sheets, I had tossed and turned in my hard sleeper for the entire night. As I struggled with my suitcase and its stubborn wheels, I thought about the client I was meeting with for breakfast in a few hours. It was the summer of 2004, and this was my first visit to Yiwu.

For the last few months I had been working at Asia Transnational, * a small sourcing company based in Nanjing, and had grown to accept that living in one of the proverbial four furnaces of China was akin to torture, yet still removed from the nine circles of hell. Hellish, however, were the hostile emails and menacing phone calls received from disgruntled clients during these long weeks of unbearable heat. In the summer of 2004, China took drastic measures to reduce its consumption of electricity. As part of this effort, many factories had their power cut off for one day a week. Office buildings could only run air conditioning for a restricted number of hours per day (not fun 
on those late nights at the office). Even the Pudong skyline, with its iconic Oriental Pearl Tower, was not allowed to "stay on" past ten.

Power cuts meant production delays, and this made even the most understanding clients lose their cool. Benjamin Franklin had great foresight: time is in fact money. In the sourcing world, a one-day delay in production can translate into one or two extra weeks at port, especially since shippers operate certain routes on a weekly basis. Under these conditions, a client could very well end up with two 40-foot containers stuck at Incheon for three weeks, lost in transshipment as they embarked on their trans-Pacific journey from Ningbo to the port of Buenaventura, Colombia.

And one of our clients in fact did. His name was Alejo Martínez, the man I had come down to Yiwu for. Within the idiosyncratic microcosm of China International, accompanying a client to Yiwu was the ultimate rite of passage. So had there been a flight running between the Nanjing and Yiwu airports, I would have certainly shown more excitement when I checked into my flashy five-star hotel.

As the receptionist kindly handed over my key card, I was reminded that breakfast began promptly at six-thirty, since guests were to set off for the markets as early as possible. My client, Alejo Martínez, was surely just as eager as any other to catch that early worm. Yet to my slight relief, our breakfast had been scheduled at seven-thirty. I was also reminded that the first floor housed a 'disco' (read brothel), as well as the indispensable karaoke bar. I was then reassured that the Western-style breakfast buffet was obviously included in the hefty price of the thirty-dollar rooms.

Señor Alejo was the most important client in my portfolio. He was also the company's largest and most loyal one. For eight long years, Asia Transnational had been Alejo's "purchasing department in Asia," a firm promise implied by the company's slogan. The company's founder and president, an American-educated Spaniard by the name of Francisco Camps, had first approached him years ago at the Canton Fair. It had been Alejo's first trip to China. He spoke no English and could not tell the difference between a bill of lading and a grocery list. Francisco considered this to be the ideal client profile for his then budding company.

When I first attended the bi-annual Canton Fair in fall of 2004, I was instructed to keep my ears open for Spanish imprecations of confusion, frustration, and (hopefully) despair. This was my queue to step in, hand out the firm's poorly designed brochures, and market the services of the company. 
Comparatively speaking, Asia Transnational was a tiny fire ant in China's competitive sourcing jungle. Yet it had found its niche, and differentiated itself from a myriad of other sourcing companies which came in all sizes and shapes. Run by Spanish-speakers, for Spanish-speaking clients.

After this initial encounter, Señor Alejo did not remain clueless for long. He had been distributing Chinese merchandise from Chinese suppliers in Bogota for several years, and had decided to take on the logical next step and move up the value chain. By the time I entered Asia Transnational and took charge of his account, he was importing three million dollars a year (and growing). He was still a tiny fish in the ocean of China's foreign trade sector, but a cash cow for a small sourcing operation like Asia Transnational.

Alejo was now Bogota's largest distributor of Chinese low-end consumer goods, most of which were eventually sold in Colombia's informal sector: from stationary, writing utensils, novelty items, and hair brushes, to mobile phone accessories, belt buckles, stickers, and cheap PVC backpacks. ${ }^{3}$ All, of course, with their corresponding pirated logos and/or otherwise proprietary cartoon characters. Hair brushes and pens were custom made by a factories in the Ningbo area, and even carried the client's trademark: "Shine."

Bi-weekly shipments of about $\$ 100,000$ in mobile phone accessories were purchased from our friendly pirate, Drake Liu, based in Guangzhou. He supplied the best Motorola, Nokia, and Samsung accessory knockoff $s$ in the market. Drake had put his guanxi with the local authorities to good use in order to avoid the hassle of possible raids. ${ }^{4}$ It was agreed that law-enforcement would turn a blind eye as long as containers were loaded at midnight. This implied staying up until 2 a.m., waiting for the company's quality control team to e-mail me the report and photographs, which I then forwarded to the client before the shipment was authorized. As with all of Alejo's purchases, I would then receive two separate invoices from the supplier: the "real" one, for client and company records, and a second invoice, listing the price of each good at only $30 \%$ of the actual value. This second invoice was to be submitted to the Colombian customs authority. After all, Colombian import duties were considerably high, and the company's policy was to look out for the clients'

3. For reasons that will become sufficiently evident, names have been altered to protect the privacy of companies, individuals, and their actions. The following is based on my experience as an account director at "Asia Transnational" in the period from April 2004 to January 2005.

4. China is Colombia's second most important import partner, with $7.6 \%$ of this country's $\$ 31.67$ billion in imports originating in China (2008 est.). Source: CIA World Factbook. 
best interests. It soon became clear to me that this was common practice. Chinese suppliers were more than wiling to provide bogus invoices.

By 2004, Alejo was no longer one of the countless "micro importers" doing business in China. He was actually ordering periodic shipments of "40-foot high-cube" containers from several suppliers. Yet Yiwu's markets were still his main source of business. That day, as I headed for the buffet, I was not only groggy but also nervous. Alejo had been coming to Yiwu about every four to six months for the last eight years. He knew the markets like the back of his hand. He had even being taking English lessons to improve his chances of communicating on his own. I had been exchanging e-mails with him every day for the last few months — phone calls with this star client were solely directed to Francisco, my boss - so I wasn't sure what to expect. Fortunately, I found him to be calm and soft spoken. With a party of raucous Russians in the table behind us, I had a hard time overhearing his detailed plans for the rest of the day.

Once we hit the "Old Market," Alejo the Serene was gone. Merchant Hyde now took his place. Asia Transnational had a partnership with Yiwu's QSC trading company, an offshoot of the Ningbo-based company from which Alejo Martínez purchased ballpoint pens. QSC provided us with an agent/interpreter and was in charge of collecting the merchandise from the different vendors at its warehouse. It then used its export license to pass the goods as its own, load them onto containers, and transport them to Ningbo port.

Derek Tao, 25, became my guide through these uncharted waters. He had been Alejo's agent for the last four years, and knew perfectly well what our client was looking for. We both found it hard to keep up with Alejo's pace. He went on to the next stall as we wrote down detailed notes and took digital photographs of every item he had chosen. Alejo was like a child on a shopping spree at Toys'R'Us. Unstoppable. We had to politely beg for a lunch break before going on to the "New Market," Futian 福田.

The "Old Market," which has since my visit been renovated, looked like any other large market in a mid-sized Chinese city. It was still loud, chaotic, and yes, filthy. It was far from what the Chinese would call "civilized" (wenming 文 明). It somehow reminded me of the semi-improvised stalls of Beijing's old Silk Market (before it too was renovated). Futian Market on the other hand, was more reminiscent of a gargantuan shopping mall. The only difference was that you could not come up to stall or shop and buy only one item. You needed to 
ask for at least a couple of boxes. And unlike prices, the minimum quantities required to place an order were reasonably low but rarely negotiable.

Alejo systematically walked through every corridor and scanned every stall, demanding to see the zui xinde 最新的 (the newest items). Together with tai gui le 太贵了 (too expensive) and pianyi yi dian 便宜一点 (a bit cheaper), this was his limited Chinese vocabulary. In his business, price and novelty were the name of the game.

Derek and I had to keep up with Señor Alejo's speed, taking pictures, making sure that we had every vendor's business card so that the items could be collected in time for shipment. When the clock struck five and the markets officially closed, it was a relief, even though I knew this would be exactly the next day's drill. My feet throbbed. My head ached. I longed for my king-size hotel bed. Yet one thing was clear: Yiwu was definitely a place like no other.

\section{The Story Behind the Stalls}

The choice to introduce Yiwu in personal terms has been a deliberate one. Doing business in China is a personal matter, regardless of the size of the company or the amount of capital involved. For the small and micro importers that visit Yiwu each year, business is yet more personal-not only in depth, but in an actual hands-on approach.

A multimillion-dollar sourcing outfit such as Hong Kong's Li \& Fung is an oddity in the China sourcing landscape. The industry is tremendously fragmented. There are Chinese trading companies of all shapes and sizes, and others run by foreigners for their co-nationals or members of their language group. Some deal with all kinds of goods, others specialize on certain products, like textiles. If you take a look at the streets of Yiwu, you wil find signs in Chinese, Cyrillic, Arabic, and Thai scripts. Some advertise trading companies; others, restaurants (and the occasional shisha bar).

The "small fries" strongly rely on these sourcing networks in order to purchase from Chinese suppliers, and definitely so if they want to purchase from Yiwu's markets. In this sense, the relationship and business practices that brought together Alejo Martínez, Asia Transnational, QSC, and myself are far from unique. To an extent, we represent nondescript buyer $X$, sourcing company $Y$, and inexperienced, underpaid employee $Z$. Yet how do these thousands of networks, revolving around Yiwu's markets, fit into the larger picture of Chinese economic and business history? 
Since the late imperial period, Zhejiang has been known for its entrepreneurial trading networks, especially those originating in the ports of Ningbo and Wenzhou. Like its neighboring southern provinces, Fujian and Guangzhou, Zhejiang province has been cursed with a mountainous terrain non-conducive to agriculture. This has left its inhabitants cornered with two economic strategies: to engage in subsistence agriculture or go out and trade. More often than not, the family 'household estate' or jia 家 has diversified its economic risks, rather than opting for "an all or nothing" approach. The family plot was not abandoned; excess male labor would then be sent out to engage in commercial pursuits.

For the Hokkien merchants

Doing business in China is a personal matter, regardless of the size of the company or the amount of capital involved. For the small and micro importers that visit Yiwu each year, business is yet more personal-not only in depth, but in an actual hands-on approach of Fujian's Minnan region, this strategy translated into the most extensive of Chinese maritime trade networks. Most of Southeast Asia was part of regular Hokkien trade routes by the early Qing. Domestically, the merchant-financiers of Huizhou had defied their native ecology by leaving Anhui province and widely relocating throughout the empire under the Ming. At a lesser scale and economic success, the merchants of Yiwu also became involved in long-distance trade.

During the Ming dynasty, Yiwu became the base for the so-called "slicedcandy" (qiao tang 敲糖) peddlers. Sugarcane was one of the few cash crops that could be grown in Yiwu and its environs (Hu 1982: 15). The sugar was then used to make a unique green-colored rock candy that was well received by consumers in the region. About $50 \%$ of Yiwu candy went through a vertically integrated process of manufacturing and distribution run by a wealthy class of local merchants. The remaining half was peddled by individual candy hawkers, carrying their product in two buckets strapped to a pole across their backs. The widespread custom was to "exchange candy for chicken feathers" 
(Yang 1979: 33), feathers which were then used to make the much needed fertilizer for Yiwu's poor soil.

According to $\mathrm{Hu}$ Qi (1982: 17), by the Qianlong reign there were about 10, 000 candy peddlers in Yiwu county, who sold their candy as far as the Anhui border or the city of Hangzhou. The sliced candy business was hard hit by the Taiping rebellion, but Yiwu peddlers continued to follow their trade routes until the collectivist policies of the 1950s.

Though rural factor allocation and the marketing of agricultural products was under bureaucratic control, the Maoist did not entirely suck the life out of rural markets. It wasn't until the Cultural Revolution decade that private markets were outlawed (Zweig 1997: 4). Though the town was far from immune to the backlashes of Maoist policy, for Yiwu, the planned economy came with a blessing: Yiwu was one of the few counties in the province which had a rail line built through it. Roads connecting Yiwu to the port cities of Ningbo and Wenzhou were also paved during this period. This would prove key once the market reforms of the early 1980s came into place.

Whether the business acumen of the long-distance candy peddlers had any direct relation with the meteoric rise of Yiwu as a market town in the 1980s is questionable. It does however hold a certain romantic appeal. The people of Yiwu are certainly convinced and have erected a monument to the candy peddlers in the city center.

One thing is clear, Yiwu's geographic curse rendered the agricultural incentive schemes of the new household responsibility system rather unappealing. Private enterprise was not fully embraced until the 1990s. The new TVEs (town and village enterprises) were essentially governmental and collective enterprises. Throughout the '80s, the state refused to free prices and put and end to rationing (Oi 1999: 2). It did however reintroduce private markets. Under the new rules of the game, Yiwu's curse proved a blessing in disguise, and its access to transportation networks, an incomparable opportunity.

According to Keith Forster (2000: 8), the Yiwu market "emerged from the netherworld in semi-approved fashion in 1979." Yiwu's Xianqian Street became the hub of this expanding marketplace. This situation put the local government in a difficult position. This was non-government sponsored economic activity and they could only turn a blind eye for so long. In 1982, after months of investigation and discussion, an official report on this matter was issued by the county government. Point Five on the document read: 
The rural market has already reached a certain scale, and if it is left alone to go its own way, business order will become even more chaotic. If it is not formally opened, market management fees and state taxes will not be able to be collected, and this will be unfavorable to the state, the masses, and the business people.

(Forster 2000: 39)

After its official recognition that year, the Yiwu market continued to grow in an endogenous, non state-led progression. It outgrew its original location and has since then been relocated on three different occasions, to larger and more established venues with every move. It presently has two main market sites as well as certain streets dedicated to specific product lines, such as stationary items. The two main markets are proudly considered to embody the "sixth generation" of Yiwu's wholesale markets.

On account of Yiwu's wholesale market, the GDP of Yiwu county has skyrocketed from a mere 128 million RMB in 1978 to 42.09 billion by 2007, thus nominally growing more than 300 -fold in a little under three decades. ${ }^{5}$ The market has been responsible for strong backward linkages into the manufacturing sector. "Build the World's Biggest Supermarket, Construct an International Shopping Heaven!" reads a sign outside Yiwu's Futian market (Eckholm 2003), but Yiwu's notoriety as a global "supermarket" is now accompanied by a growing reputation as the world's "sock town." Yiwu's Fenli factory is one of those dedicated to this trade. By 2004, it was already producing over three billion pairs of socks for Wal-Mart, Pringle, and Disney (Sommerville 2005). There have also been substantial forward linkages in the tertiary sector. The city is now teeming with high-rise, luxury hotels and ostentatious restaurants struggling to cater to a world of parochial palates.

By 2006, over 400,000 commodities were being sold in Yiwu markets, across 1901 different categories and 43 industries (Ding 2006: 5). It has been called "Trinket Supplier of the World" for a reason (Eckholm 2003). But what exactly is bought and sold at Yiwu? A full list would be endless and dull, but a short list should prove illustrative:

- Arts and crafts: gift items made of glass, wood or metal; beads; Christmas products.

5. Guanxi 关系, which broadly means "relations" or "connections," features prominently in discussions of Chinese business culture. 
- Gardening products and artificial flowers and plants.

- Umbrellas (yes, a full section of the market is devoted to them).

- Stationery: ballpoint pens, fountain pens, pencils, erasers, notebooks, paper products, etc...

- Sports items

- Clocks and watches (the place to buy cheap Rolexes in bulk)

- Sunglasses

- Kitchen and bathroom hardware (and basically any kind of plastic container imaginable)

- Toys (mostly of the smaller, Happy Meal variety.) Read copyright infringements galore.

- Candles

- Cosmetic and "jewelry" (rings, earrings, necklaces, hairpins, bracelets, ankle bracelets, toe rings, fake tattoos, wigs)

- Mobile phone accessories

- Small electronic products: radios, voice recorders, CD/VCD/DVD/MP3 players, earphones, microphones.

- Leather products: bags, belts, wallets, purses.

- Shoes

- Fabrics

- Socks

The success of Yiwu over the last twenty years has been largely dependent on economies of scope: its products come in all shapes, (smells), and sizes. In 2003, a New York Times correspondent interviewed a particular successful stall owner by the name of Jin Xiaoqin. Together with her husband, she owned a factory with 50 employees. That year she was making a killing by selling an unlikely mass-produced export: glow-in-the-dark figurines of Jesus and Mary to be sold in South Korea and the Americas (Eckholm 2003). The success behind the so-called "Yiwu model" (Yiwu moshi 义乌模式) has been fluidity and adaptability: the ability to constantly churn out new products and stay ahead of every passing fad-and, above all, do it cheaply (Guo 2006: 250). For Ms Jin, the shimmering madonnas of 2003 may well turn out to be the glowing Ganeshes demanded by Hindu consumers in 2010.

For many Chinese, Yiwu has also acquired its own special glow. This boom town is now known as "Golden Yiwu" (jinse Yiwu 金色义乌). Yiwu is considered to embody the "Zhejiang spirit." A Chinese scholarly journal explains 
this success quite simply: "Jewish people and the people of Zhejiang are the most skilled and competitive in the business world." (Guo 2006: 250) In fact, Zhejiang's industrial sector stands out from that of any other province in China: the contribution by the state sector is the lowest across the entire country. For a coastal province, foreign investment has also been surprisingly minimal (Forster 2000: 5). After Deng's "Reform and Opening," the Smithian invisible hand seems to have taken hold over much of Zhejiang, starting from the grassroots. Yesterday's peasants are today's nouveaux riches.

Unlike Shenzhen, its high-profile cousin, Yiwu was never designated as a SEZ or attracted FDI. It has not been a flagship for the developmental policies of "socialism with Chinese characteristics." Both have miraculously risen from in the last twenty years. For millions of Chinese, Shenzhen and Yiwu are not geographical locations per se, but components of the modern collective imagination. They represent, at least in theory, the road to wealth. Many do migrate to Yiwu (or Shenzhen) and make it big. Others are less lucky, exchanging the toils of the rice field for a lumpen existence, sewing socks for sixteen hours a day.

Behind the glitzy veneer, there is always more than meets the eye. John Qin, the Chinese VP of Asia Transnational, had this very clear. "The people of Yiwu," he once mentioned in a cautionary tone, "are so poor that all they have is money."

\section{Going Global}

A simple Google search for the word "Yiwu" yields 3,420,000 different webpages: that of the official county-level city government, the official commodities fair, as well as those of a number of factories and export trading companies. When the search is repeated with the Chinese characters 义乌, it yields $16,200,000$ hits. As the Chinese would say, the Yiwu market is definitely "hot." And it is apparently so on a global scale.

For the last decade or so, Yiwu has ranked number one among China's wholesale markets (Feng 2004: 28). This has not only responded to domestic demand, but also to the growing number of foreign imports. International buyers began to visit Yiwu in the early 1990s. By 1999, Yiwu was exporting goods to 99 countries. By 2002, the number had risen to 160 . The statistics are hard to come by, but the myriad of smaller transactions made by micro 
and small importers should intuitively add up to a significant proportion of exports.

Much noise has been made in the worldwide press regarding Wal-Mart's billions of dollars in purchases from China, or of Lenovo's takeover of IBM's personal computer division. But the majority of Chinese businesses do not operate in modern corporate forms. Many are small family-owned ventures (with a few dozen workers at most), linked to global consumers by a web of market vendors, trading companies, and foreign distributors. These networks make it possible for a Libyan schoolboy to buy a pair of sneakers from Wenzhou in a street market in downtown Tripoli. All thanks to heated negotiations at an Yiwu market stall-in a garbled mixture of the local Jinhua dialect, Libyan Arabic, and pidgin English-as well as the container services of shipping giants such as $\mathrm{P} \& \mathrm{O}$ Nedlloyd. Thinking big is undisputedly important, but so is considering the view from the bottom. miv

\section{References}

Ding Ke. 2006. "Distribution System of China's Industrial Clusters: Case Study of Yiwu China Commodity City," Discussion paper no. 75. Tokyo: Institute of Developing Economies.

Eckholm, Erik. 2003. “The Tide of China's Migrants: Flowing to Boom, or Bust?” New York Times. 29 July.

Feng Shesong 冯拾松. 2004. “Yiwu Zhongguo xiao shangpin cheng guojihuajingying de guangdu yu shendu yanjiu 义乌中国小商品城国际化经营的 广度与深度研究," Shangye jingji yu guanli 商业经济与管理 1: 28-30.

Forster, Keith, ed. 2000. The Phenomenal Rise of the Yiwu Small-Commodities Market in Zhejiang Province. The Chinese Economy: translations and studies, vol. 33, no. 5. Armonk, NY: M.E. Sharpe.

Guo Xingbao 郭兴宝. 2006. “Yiwu de xiao shangpin shichang de chenggong yinsu tanxi 义乌的小商品市场的成功因素探析, "Shangchang xiandaihua 商场现代化 13: 250.

Hu Qi 胡崎. 1982. “Yiwu de Qiaotang bang 义乌的敲糖帮," Zhejiang wenshi ziliao xuanji 浙江文史资料选集, Hangzhou: Zhejiang Renmin chubanshe 浙江人民出版社, translated by M.E. Sharpe, in Keith Forster, ed., The Phenomenal Rise of the Yiwu Small-Commodities Market in Zhejiang Province.

Oi, Jean. 1999. Rural China Takes Off: Institutional Foundations of Economic Reform. Berkeley: University of California Press. 
Sommerville, Quentin. 2005. "The Rapid Rise of China's Sock Town," BBC News Service. 29 September. http://news.bbc.co.uk/2/hi/business/4287398. stm, accessed 21 April 2007.

Yang Shouchun 杨寿春. 1979. "Jimao huantang de bolanggu you xiangle 鸡毛换糖的拨浪鼓又响了,” Zhejiang ribao 浙江日报, 24 March 1979, translated by M.E. Sharpe, in Keith Forster, ed., The Phenomenal Rise of the Yiwu Small-Commodities Market in Zhejiang Province.

Zweig, David. 1997. Freeing China's Farmers: Rural Restructuring in the Reform Era. Armonk, NY: M.E. Sharpe.

Figures cited by Ding (2006: 4) and the China Statistical Data Network (Zhongguo tongjixinxi wang 中国统计信息网, www.tjcn.org). It is interesting to point out that per capita GDP figures that take 1978 as the index, show that once controlled for inflation, Yiwu's GDP per capita went from a 100 to 2,999 in the first two decades of reform (Forster 2000: 9). 